\title{
Glutamine promotes Hsp70 and inhibits $\alpha$-Synuclein accumulation in pheochromocytoma PC12 cells
}

\author{
HAIYANG WANG, CHONGYANG TANG, ZHENFENG JIANG, XIAO ZHOU, JIANHANG CHEN, \\ MENG NA, HONG SHEN and ZHIGUO LIN
}

Department of Neurosurgery, The First Affiliated Hospital of Harbin Medical University, Harbin, Heilongjiang 150001, P.R. China

Received October 22, 2015; Accepted March 10, 2017

DOI: $10.3892 /$ etm.2017.4580

\begin{abstract}
Hsp70 regulates $\alpha$-Synuclein ( $\alpha$-Syn) degeneration in Parkinson's disease (PD), indicating that Hsp70 promotion may be able to prevent or reverse $\alpha$-Syn-induced toxicity in PD. Additionally, it has been demonstrated that glutamine (Gln) enhances Hsp70 expression. In the present study, Gln-induced Hsp70 promotion in pheochromocytoma was investigated with reverse transcription- quantitative polymerase chain reaction and western blotting methods. Then it was observed whether heat shock factor (HSF)-1 was required for this phenomenon with an RNA interference strategy. The regulatory role of Gln on $\alpha$-Syn degeneration was also determined in the $\alpha$-Syn-overexpressed PC12 [PC12 $(\alpha-S y n+)]$ cells, which were treated with or without the proteasomal inhibitor lactacystin (Lac). The results demonstrated that treatment with $\geq 10 \mathrm{mM}$ Gln significantly increased Hsp70 mRNA and protein levels $(\mathrm{P}<0.05)$ and that this promotion was HSF-1-dependent, as HSF-1 knockout with HSF-1-specific small interfering RNA abrogated Hsp70 promotion in PC12 ( $\alpha$-Syn+) cells . Furthermore, Gln treatment markedly upregulated $\alpha$-Syn degeneration in PC12 $(\alpha-S y n+)$ cells, which was significantly reduced $(\mathrm{P}<0.05)$ in the presence of Lac. Therefore, the present study suggests that Gln is able to induce the promotion of Hsp70 expression in PC12 cells in an HSF-1-dependent manner and that Gln-mediated Hsp70 promotion may increase $\alpha$-Syn degradation even in the presence of proteasomal inhibitor. Thus, glutamine may be a potential therapeutic agent to prevent $\alpha$-Syn aggregation in PD.
\end{abstract}

Correspondence to: Dr Zhiguo Lin, Department of Neurosurgery, The First Affiliated Hospital of Harbin Medical University, 23 Youzheng Street, Nangang, Harbin, Heilongjiang 150001, P.R. China

E-mail: zhiguolinhlj@163.com

Key words: glutamine, heat shock protein 70, heat shock factor-1, $\alpha$-Synuclein, proteasomal inhibitor

\section{Introduction}

Parkinson's disease (PD) is a neurodegenerative disorder (1) characterized by the degradation of dopaminergic cells within the substantia nigra pars compacta (2) and by the aberrant aggregation of $\alpha$-Synuclein ( $\alpha$-Syn) in the dorsal motor nucleus of the vagus (3-5). $\alpha$-Syn belongs to a family of structurally associated proteins in the brain $(6,7)$, which serve an important role in neurotransmitter release (8) by promoting the assembly of the soluble N-ethylmaleimide-sensitive fusion attachment protein machinery (9). Impaired $\alpha$-Syn degeneration has been widely accepted to be the key pathological course of pathogenic protein accumulation (10). However, the mechanism that impairs the degeneration of $\alpha$-Syn in PD remains to be determined $(11,12)$.

Besides the increased $\alpha$-Syn synthesis in PD (13), aberrant $\alpha$-Syn aggregation in PD may predominantly be caused by impaired $\alpha$-Syn degradation (14-16). Molecular chaperones, most of which are heat shock proteins (Hsps), are the primary defense against protein misfolding and aggregation, as they bind to unfolded proteins and maintain them in a folding-competent state. In addition, they may be associated with dissolving aggregates and targeting misfolded proteins for degradation (17). It has also been demonstrated that Hsp overexpression may refold and ameliorate aberrantly aggravated $\alpha$-Syn $(18,19)$, suggesting that this may be the key role of Hsp70 in PD $(19,20)$. The negative regulation of $\alpha$-Syn aggregation and of $\alpha$-Syn-induced cellular toxicity by Hsp70 has been previously demonstrated $(20,21)$. Therefore, Hsp70 may be a potential therapeutic agent for the treatment of $\mathrm{PD}$, as it may block and reverse $\alpha$-Syn-induced toxicity.

The ubiquitin-proteasome system is the principal degradation system for short-lived and misfolded proteins in eukaryotic cells. The ubiquitinated target protein containing the serially-activated Elubiquitin-activating enzyme, E2 ubiquitin-conjugating enzyme and the E3 ligase is recognized by and degraded in the proteasome by the $26 \mathrm{~S}$ proteasome complex $(22,23)$. Recently, it has been determined that the dysfunction of the lysosome and ubiquitin-proteasome system is associated with the abnormal aggregation of $\alpha$-Syn in neuroblastoma PC12 cells (22). Furthermore, enhanced ubiquitin-dependent degradation of $\alpha$-Syn by neural precursor cell expressed developmentally down-regulated protein 4 
was confirmed in an animal model of PD (24). However, the association between the molecular chaperone- and the ubiquitin/proteasome system-mediated degradation of $\alpha$-Syn in neuroblastoma cells remains to be elucidated.

In the present study, the regulatory role of glutamine on Hsp70 expression in neuroblastoma PC12 cells was investigated. Subsequently, the regulatory role of glutamine on $\alpha$-Syn degradation in $\alpha$-Syn-overexpressed PC12 cells with or without treatment with the proteasomal inhibitor lactacystin (Lac) was also investigated. The present study indicates that glutamine may be effective at preventing $\alpha$-Syn aggregation in PD.

\section{Materials and methods}

Reagents, cell culture and treatments. L-glutamine (Gln; Thermo Fisher Scientific, Inc., Waltham, MA, USA) and Lac (Santa Cruz Biotechnology, Inc., Dallas, TX, USA) were dissolved in Dulbecco's modified Eagle's medium (DMEM) supplemented with 2\% FBS (both from Invitrogen; Thermo Fisher Scientific, Inc.). Cells from the pheochromocytoma cell line PC12 were purchased from the American Type Culture Collection (Manassas, VA, USA) and were cultured for 2 days to $\sim 85 \%$ confluencu in the DMEM supplemented with $10 \%$ (for growth) or $2 \%$ (for maintenance) FBS and $100 \mathrm{U} / \mathrm{ml}$ penicillin/streptomycin (CSPC Pharmaceutical Group, Ltd., Shijiazhuang, China) at $37^{\circ} \mathrm{C}$ in a humid (100\% humidity) incubator. For Gln treatment, PC12 cells at $85 \%$-confluence were incubated at $37^{\circ} \mathrm{C}$ with DMEM supplemented with $2 \%$ FBS and with $0,5,10$ or $20 \mathrm{mM}$ Gln for $0,4,8,12,24$ or 48 h. For Lac treatment, PC12 cells at $85 \%$ confluence were incubated at $37^{\circ} \mathrm{C}$ with $0,2,5$ or $10 \mu \mathrm{M} \mathrm{Lac}$ for $0,6,12$ or $24 \mathrm{~h}$. To knockdown expression of heat shock factor (HSF), 20 or 40 nM HSF-1-specific short interfering (si)RNA (5'-UGAUGU CGGAGAUGAUGGGTT-3') or control siRNA (siRNA-con, scramble; Sangon Biotech Co., Ltd., Shanghai, China) was transfected into PC12 ( $\alpha$-Syn+) cells using Lipofectamine RNAiMax transfection reagent (Invitrogen; Thermo Fisher Scientific, Inc.) to abrogate HSF-1 expression.

To induce overexpression of $\alpha-S y n$ in PC12 cells, the $\alpha$-Syn coding sequence was amplified with $P f u$ DNA polymerase (Promega Corporation, Madison, WI, USA) and was cloned into the pcDNA3. 1(+) eukaryotic expression vector (Invitrogen; Thermo Fisher Scientific, Inc.). $\alpha$-Syn cDNA was synthesized via reverse transcription $\left(95^{\circ} \mathrm{C}\right.$ for $2 \mathrm{~min}$ followed by $42^{\circ} \mathrm{C}$ for $60 \mathrm{~min}$ ) with poly-dT primer (5'-TTTTTTTTT TTT-3') (Invitrogen; Thermo Fisher Scientific, Inc.). The polymerase chain reaction (PCR) was performed under the conditions of an initial denaturation for $1 \mathrm{~min}$ at $95^{\circ} \mathrm{C}$ followed by 40 cycles of denaturation for $40 \mathrm{sec}$ at $94^{\circ} \mathrm{C}$, annealing for $1 \mathrm{~min}$ at $55^{\circ} \mathrm{C}$ and extension for $5 \mathrm{~min}$ at $72^{\circ} \mathrm{C}$, and a final extension for $10 \mathrm{~min}$ at $72^{\circ} \mathrm{C}$. The $\alpha$-Syn-specific primer pairs were as follows: Forward, 5'-CTC CTC GAG AGG AGA AGG AGA AGG-3'; and reverse, 5'-CGC AAG CTT TAT TTT CAT ATA TGT-3'. The recombinant $\alpha$-Syn-pcDNA3. 1(+) plasmid was subsequently transfected using Lipofectamine 2000 (Invitrogen; Thermo Fisher Scientific, Inc.) into PC12 cells. The coding sequence for chloramphenicol acetyl transferase (CAT) was also cloned into pcDNA3. 1(+) to construct CAT-pcDNA3. 1(+) plasmids, which were also transfected into
PC12 cells as a control with Lipofectamine 2000 (Invitrogen; Thermo Fisher Scientific, Inc.). PC12 cells following transfection were cultured at $37^{\circ} \mathrm{C}$ (medium was replaced every $48 \mathrm{~h}$ ) in the presence of $200 \mu \mathrm{g} / \mathrm{ml} \mathrm{G} 418$ (Thermo Fisher Scientific, Inc.) to select the positive clone, PC12 ( $\alpha$-Syn+). PC12 (con) cells were maintained in the presence of $80 \mu \mathrm{g} / \mathrm{ml} \mathrm{G} 418$.

$m R N A$ preparation and quantitative analysis with reverse transcription-quantitative PCR (RT-qPCR). Cellular mRNA was prepared using an mRNA Isolation and Purification kit (Clontech Laboratories, Inc., Mountainview, CA, USA) according to the manufacturer's protocol. The mRNA expression of Hsp70, HSF-1, or $\alpha$-Syn was quantified using RT-qPCR. cDNA for each marker was synthesized using the Quantitect Reverse Transcription kit (Qiagen, Inc., Valencia, CA, USA) under the conditions of $95^{\circ} \mathrm{C}$ for $30 \mathrm{sec}$ followed by $42^{\circ} \mathrm{C}$ for 60 min with poly-dT primer (5'-TTTTTTTTTTTT-3'). qPCR was performed using a SYBR-Green-based Quantitative PCR kit (Sigma-Aldrich; Merck KGaA, Darmstadt, Germany) with a Lightcycler 480 II (Roche Diagnostics GmbH, Mannheim, Germany) under the following conditions: $95^{\circ} \mathrm{C}$ for $1 \mathrm{~min}$ (1 cycle), followed by 40 cycles of $94^{\circ} \mathrm{C}$ for $15 \mathrm{sec}, 55^{\circ} \mathrm{C}$ for $15 \mathrm{sec}$ and $70^{\circ} \mathrm{C}$ for $20 \mathrm{sec}$. The primer sequences were as follows: $\alpha$-Syn forward, 5'-AGGACTTTCAAAGGCCAAGG-3'; $\alpha$-Syn reverse, 5'-TCC TCCAACATTTGTCACTTGC-3'; HSP70 forward, 5'-TGTGTCTGCTTGGTAGGAATGGTG GTA-3', HSP70 reverse, 5'-TTACCCGTCCCCGATTTGAAG AAC-3'; HSF-1 forward, 5'-CGACAGTGGCTCAGCACA TTCC-3', HSF-1 reverse, 5'-CAGCTCGGTGATGTCGGA GATG-3'; $\beta$-actin forward, 5'-TGTCCACCTTCCAGCAGA TGT-3', $\beta$-actin reverse, 5'-AGCTCAGTAACAGTCCGCCTA GA-3'. The $2^{-\triangle \Delta C q}$ method was used to relatively determine the mRNA level for each marker, with $\beta$-actin as an internal control (25). This experiment was repeated three times.

Western blotting. Following treatment, PC12 (con) or PC12 $(\alpha-$ Syn +$)$ cells were washed with cold phosphate-buffered saline, and cytoplasmic proteins were isolated using the NE-PER Nuclear and Cytoplasmic Extraction kit (Thermo Fisher Scientific, Inc.) and a protease inhibitor cocktail (Abcam, Cambridge, UK). Protein concentration was quantified with bicinchoninic acid protein assay reagent (Sigma-Aldrich; Merck KGaA). Proteins were then subjected to sodium dodecyl sulphate-polyacrylamide gel electrophoresis (SDS-PAGE) electrophoresis with $10 \%$ gradient gel. Separated proteins were subsequently transferred to PVDF membranes (EMD Millipore, Billerica, MA, USA), which were blocked with $2 \%$ bovine serum albumin (Sigma-Aldrich; Merck KGaA) at $4^{\circ} \mathrm{C}$ overnight. Primary rabbit polyclone antibodies against Hsp70 (1:1,000; ab2787; Abcam, Cambridge, UK), HSF-1 (1:500; sc-17756; Santa Cruz Biotechnology, Santa Cruz, CA, USA), $\alpha$-Syn (1:1,000; \#2642; Cell Signaling Technology, Inc., Danvers, MA, USA) or $\beta$-actin (1:2,000; A2066; Sigma-Aldrich; Merck KGaA) were incubated to allow specific binding for $2 \mathrm{~h}$ at $4^{\circ} \mathrm{C}$. The horseradish peroxidase-conjugated secondary anti-rabbit antibody $(1: 5,000 ; 111-035-003$; Jackson ImmunoResearch Laboratories, Inc., West Grove, PA, USA) was used to detect the specific antigen-antibody binding for $1 \mathrm{~h}$ at room temperature. Finally, each target protein was visualized using an enhanced chemiluminescence detection 
A

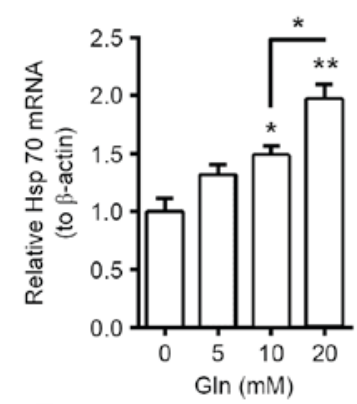

D

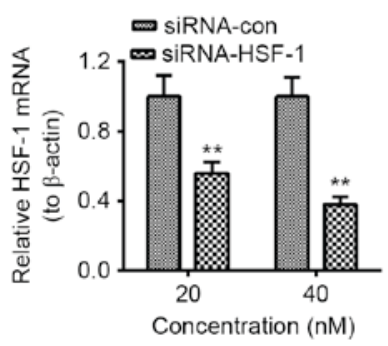

G

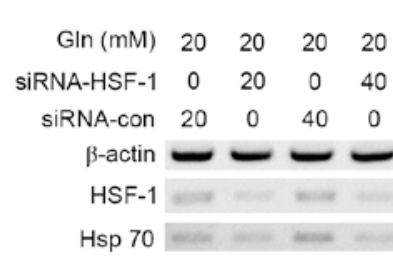

B

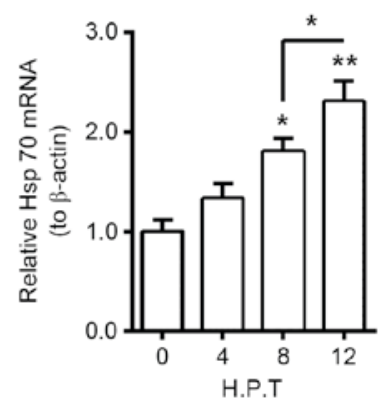

E

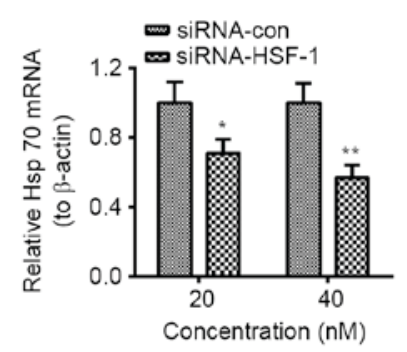

H
C

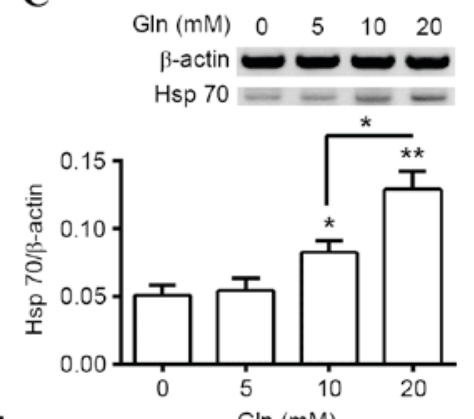

F

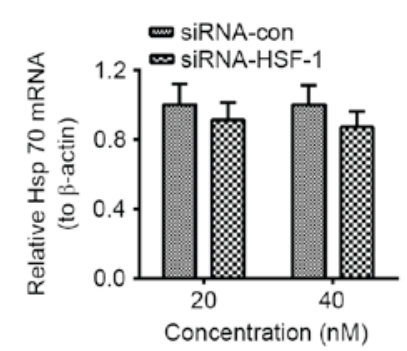

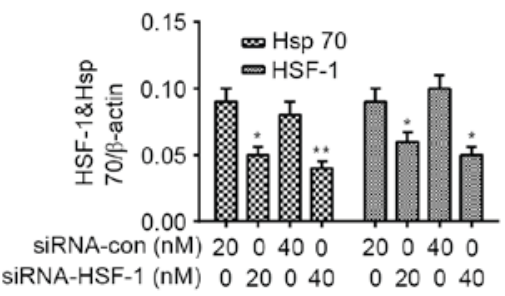

Figure 1. Gln upregulates Hsp70 expression in PC12 cells HSF-1-dependently. (A) Levels of Hsp70 mRNA in PC12 cells following treatment with 0, 5, 10, or $20 \mathrm{mM}$ Gln for $8 \mathrm{~h}$. (B) Levels of Hsp70 mRNA in PC12 cells following $20 \mathrm{mM}$ Gln treatment for 0, 4, 8 or 12 h. (C) Western blot analysis of Hsp70 protein levels in PC12 cells following treatment with $0,5,10$, or $20 \mathrm{mM}$ Gln for $24 \mathrm{~h}$, with $\beta$-actin as an internal control. (D) Levels of HSF-1 mRNA in PC12 cells $12 \mathrm{~h}$ following transfection with 20 or $40 \mathrm{nM}$ siRNA-HSF-1 or siRNA-con. Levels of Hsp70 mRNA in PC12 cells (E) with or (F) without the treatment with 20 mM Gln, following transfection with 20 or 40 nM siRNA-HSF-1 or siRNA-Con. (G and H) Hsp70 and HSF-1 protein levels measured via western blot analysis in PC12 cells transfected with 20 or $40 \mathrm{nM}$ siRNA-HSF-1, or siRNA-con, in the presence of $20 \mathrm{mM}$ Gln. All experiments were performed in triplicate and data are presented as the mean \pm standard deviation. ${ }^{*} \mathrm{P}<0.05,{ }^{* *} \mathrm{P}<0.01$ vs. control $(0 \mathrm{~h}, 0 \mathrm{mM}$ Gln or siRNA Con as indicated). Gln, glutamine; Hsp, heat shock protein; HSF, heat shock factor; siRNA, short interfering RNA; siRNA-HSF-1, HSF-1-targeted siRNA; con, control; H. P. T., h post-transfection.

kit (GE Healthcare Life Sciences, Chalfont, UK) according to the manufacturer's protocol.

Proteasomal activity assay. Proteasome activity in PC12 (con) or PC12 $(\alpha-\mathrm{Syn}+)$ cells was assayed, following cell lysis, by measuring the release of 7-amino-4-methylcoumarin (AMC) from the fluorogenic peptides Suc-Leu-Leu-Val-Tyr-AMC and Z-Leu-Leu-Glu-AMC. Cells were lysed in $20 \mathrm{mM}$ Tris-HCl, $1 \mathrm{mM}$ EDTA buffer ( $\mathrm{pH}$ 7.5) and were centrifuged at $12,000 \mathrm{x} \mathrm{g}$ for $30 \mathrm{~min}$ at $4^{\circ} \mathrm{C}$ to remove cellular debris. The supernatant was collected and was diluted to a concentration of $100 \mu \mathrm{g} / \mu \mathrm{l}$. Protein sample $(1-3 \mu \mathrm{l})$ was added to the assay mixture in a total volume of $300 \mu \mathrm{l}$ containing $50 \mu \mathrm{M}$ Z-Leu-Leu-Glu-AMC, $50 \mu \mathrm{M}$ Suc-Leu-Leu-Val-Tyr-AMC, $5 \mathrm{mM}$ adenosine triphosphate and $5 \mathrm{mM} \mathrm{Mg}$ acetate in Tris-EDTA buffer with or without Lac $(0,2,5$ or $10 \mu \mathrm{M})$. The mixture was incubated at $37^{\circ} \mathrm{C}$ for $30 \mathrm{~min}$ followed by the fluorescence measurement at $\lambda \operatorname{ex} 360 \mathrm{~nm}$ and $\lambda$ em $465 \mathrm{~nm}$ with a fluorescence spectrophotometer (Hitachi Fluorescence Spectrophotometer F-2000; Hitachi Ltd., Tokyo, Japan). The assay produced proportional responses up to $300 \mu \mathrm{g}$ protein. Proteasomal activity was presented as a relative level to the control group ( $0 \mu \mathrm{M}$ Lac or $0 \mathrm{mM}$ Gln). Five replicates were performed for each experiment.

Statistical analysis. Quantitative results were presented as the mean \pm standard deviation. The difference between the experimental and control groups was analyzed using Student's two-tailed t-test, with SPSS 13.0 (SPSS, Inc., Chicago, IL, USA). $\mathrm{P}<0.05$ was considered to indicate a statistically significant difference.

\section{Results}

Gln upregulates Hsp70 expression in PC12 neuroblastoma cells HSF-1-dependently. Previous studies have demonstrated that Gln enhances the expression of Hsp (26-29), which serves a key regulatory role in $\alpha$-Syn degradation. Therefore, the regulation by Gln on Hsp70 expression in PC12 neuroblastoma cells was investigated. Hsp70 mRNA expression was significantly increased in PC12 cells following Gln treatment for $8 \mathrm{~h}(\mathrm{P}<0.05$ for $10 \mathrm{mM}$; $\mathrm{P}<0.01$ for $20 \mathrm{mM})$ and there was a significant increase in Hsp70 mRNA expression in the $20 \mathrm{mM}$ group compared with the $10 \mathrm{mM}$ group ( $\mathrm{P}<0.05$; Fig. 1A). 
A

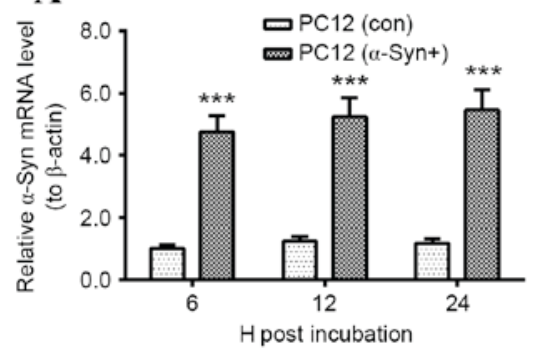

C

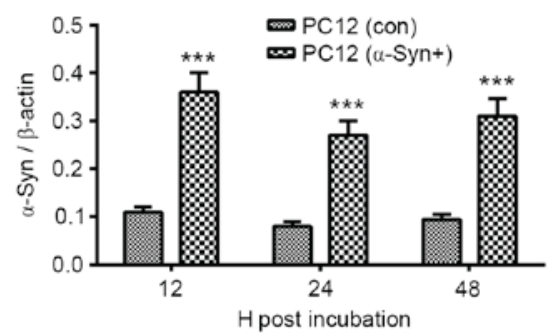

$\mathbf{E}$

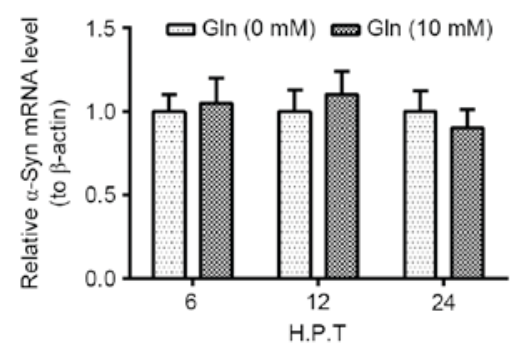

B

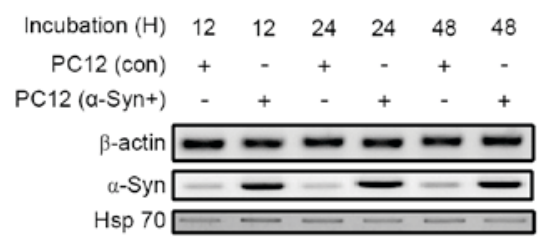

D

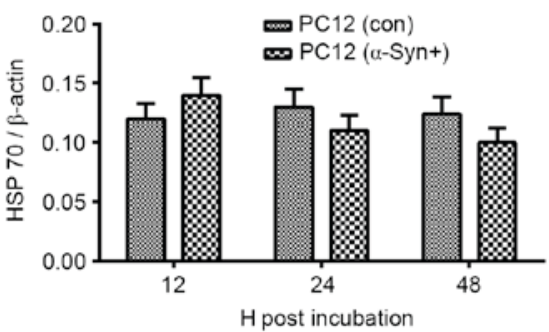

$\mathbf{F}$
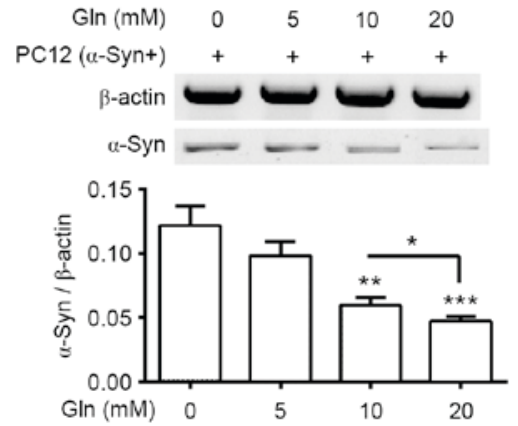

Figure 2. Gln treatment promotes $\alpha$-Syn degradation in PC12 ( $\alpha$-Syn+) cells. (A) Levels of $\alpha$-Syn mRNA in PC12 ( $\alpha$-Syn+) cells or in PC12 (con) cells, following an incubation for 6, 12 or $24 \mathrm{~h}$. (B) Western blot analysis of $\alpha$-Syn and Hsp70 protein levels in PC12 ( $\alpha$-Syn+) or PC12 (Con) cells, following an incubation time for 12, 24 or $48 \mathrm{~h}$. Relative levels of (C) $\alpha$-Syn or (D) Hsp70 in PC12 ( $\alpha$-Syn+) or PC12 (Con) cells, following an incubation time for 12, 24 or 48 h. (E) Relative levels of $\alpha$-Syn mRNA in the PC12 ( $\alpha$-Syn+) cells with or without 10 mM Gln treatment for 6,12 or 24 h. (F) Western blot analysis of $\alpha-S y n$ protein levels in the PC12 ( $\alpha$-Syn+) cells, following the treatment with $0,5,10$ or $20 \mathrm{mM}$ Gln for $24 \mathrm{~h}$. All results are presented as mean \pm standard deviation for triple experiments. ${ }^{*} \mathrm{P}<0.05,{ }^{* *} \mathrm{P}<0.01,{ }^{* * *} \mathrm{P}<0.001$ vs. control. Gln, glutamine; $\alpha$-Syn, $\alpha$-Synuclein; $\mathrm{PC} 12(\alpha-$ Syn +$)$, $\alpha$-Syn-overexpressed PC12; con, control; Hsp, heat shock protein; H. P. T., h post transfection; H, h.

Such promotion was also time-dependent, as significant Hsp70 mRNA upregulation was observed at $8 \mathrm{~h}$ following the treatment with $20 \mathrm{mM} \mathrm{Gln}(\mathrm{P}<0.05)$ and at $12 \mathrm{~h}$ post treatment $(\mathrm{P}<0.01)$ compared with cells that were not treated with GIn; with a significant increase in Hsp70 mRNA levels at $12 \mathrm{~h}$ compared with $8 \mathrm{~h}(\mathrm{P}<0.05$; Fig. 1B). Furthermore, promotion of Hsp70 protein expression by Gln was also confirmed in PC12 cells, as significantly increased levels of Hsp70 were detected in the $24 \mathrm{~h}$ Gln-treated PC12 cells compared with those that were not treated with $\mathrm{Gln}(\mathrm{P}<0.05$ for $10 \mathrm{mM} ; \mathrm{P}<0.01$ for $20 \mathrm{mM}$; Fig. 1C), with a significant increase observed in the $20 \mathrm{mM}$ group compared with the $10 \mathrm{mM}$ group $(\mathrm{P}<0.05)$.

Given the key role of HSF in the expression of Hsps, including Hsp70 (30), the association of HSF-1 knockdown on Gln-promoted Hsp70 expression was investigated. Transfection with the HSF-1-specific siRNA, siRNA-HSF-1, significantly downregulated levels of HSF-1 mRNA $(\mathrm{P}<0.01$ for 20 and $40 \mathrm{nM}$ ) in PC12 cells (Fig. 1D) and significantly reduced Hsp70 mRNA levels in PC12 cells treated with $20 \mathrm{nM}$ Gln $(\mathrm{P}<0.05$ for $20 \mathrm{nM}$ and $\mathrm{P}<0.01$ for $40 \mathrm{nM}$; Fig. 1E), compared with siRNA-con. Notably, downregulation of Hsp70 mRNA was not significant in PC12 cells transfected with siRNA-HSF1 that did not receive Gln treatment (Fig. 1F). In addition, western blotting demonstrated that HSF-1 and Hsp70 were significantly downregulated following siRNA-HSF-1 transfection (Hsp70, P<0.05 for $20 \mathrm{nM}, \mathrm{P}<0.01$ for $40 \mathrm{nM}$; HSF-1, $\mathrm{P}<0.05$ for both; Fig. $1 \mathrm{G}$ and $\mathrm{H}$ ). These results suggest that Gln promotes Hsp70 expression HSF-1-dependently in PC12 cells.

Upregulation of Hsp70 by Gln increases $\alpha$-Syn degradation in PC12 ( $\alpha$-Syn+) cells. To investigate the regulation of Gln-promoted Hsp70 on $\alpha$-Syn degradation in PC12 cells, wild-type $\alpha$-Syn was overexpressed in PC12. Significantly increased levels of $\alpha$-Syn mRNA were observed in PC12 $(\alpha-S y n+)$ cells following incubation with $\alpha$-Syn for 6,12 or $24 \mathrm{~h}(\mathrm{P}<0.001$ for all; Fig. 2A). Levels of $\alpha$-Syn protein were also significantly higher in PC12 $(\alpha-\mathrm{Syn}+)$ cells than in the control PC12 (con) cells following incubation for 12, 24 or 48 h $(\mathrm{P}<0.001$ for all; Fig. 2B and C). Subsequently, it was 
A

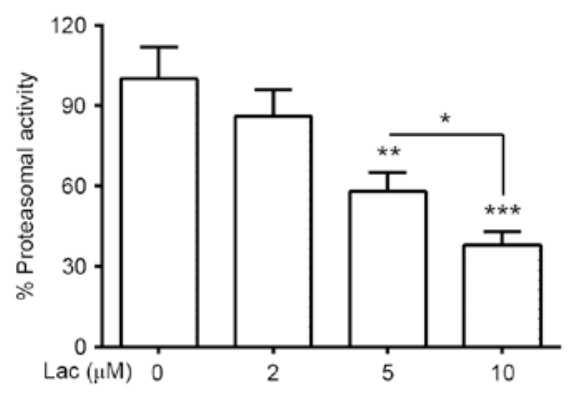

C

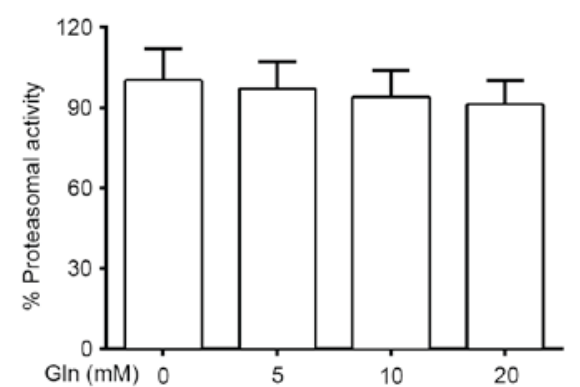

B

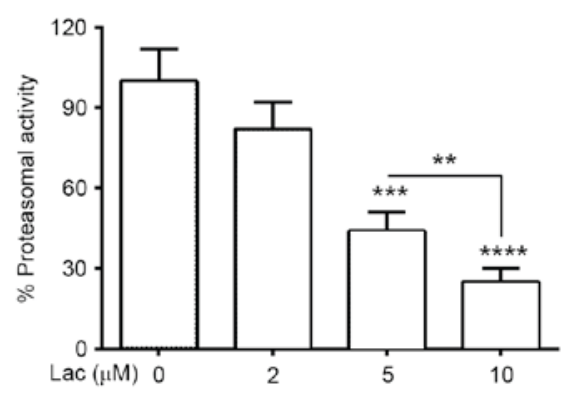

D

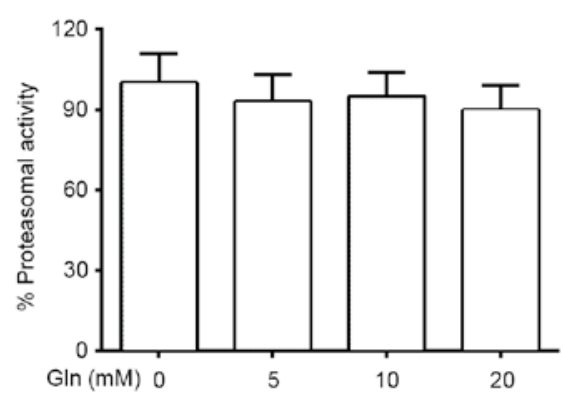

Figure 3. Proteasomal activities in PC12 $(\alpha-$ Syn +$)$ cells treated with Lac and/or Gln. Proteasomal activity in (A) PC12 ( $\alpha$-Syn+) or (B) PC12 (con) cells treated with $0,2,5$ or $10 \mu \mathrm{M} \mathrm{Lac}$ for $24 \mathrm{~h}$. Proteasomal activity in (C) PC12 ( $\alpha$-Syn+) or (D) PC12 (con) cells treated with 0,5 , 10 or 20 mM Gln for 24 h. Each value was relative to the proteasomal activity in PC12 $(\alpha-S y n+)$ cells treated without Lac or Gln for $24 \mathrm{~h}$. Data was presented as mean \pm standard deviation of four independent results ${ }^{*} \mathrm{P}<0.05,{ }^{* *} \mathrm{P}<0.01,{ }^{* * *} \mathrm{P}<0.001,{ }^{* * * *} \mathrm{P}<0.0001$ vs. $0 \mu \mathrm{M}$ Lac. PC12 ( $\alpha-$ Syn+), $\alpha$-Syn-overexpressed PC12; $\alpha$-Syn, $\alpha-$ Synuclein; Lac, lactacystin; Gln, glutamine; con, control.

investigated whether overexpressed $\alpha$-Syn regulated Hsp70 expression and it was determined that there was no significant difference in Hsp70 mRNA levels between PC12 $(\alpha-S y n+)$ and PC12 (con) cells (Fig. 2D). Gln was also demonstrated to serve a regulatory role on $\alpha$-Syn degradation in PC12 ( $\alpha$-Syn+) cells. Treatment with $10 \mathrm{mM}$ Gln treatment had no significant influence on the $\alpha$-Syn mRNA levels in the PC12 $(\alpha-S y n+)$ cells, at 6, 12 or $24 \mathrm{~h}$ following treatment (Fig. 2E). However, levels of $\alpha$-Syn protein were significantly downregulated in PC12 $(\alpha-S y n+)$ cells treated with 10 or $20 \mathrm{mM}$ Gln $(\mathrm{P}<0.01$ and $\mathrm{P}<0.001$, respectively; Fig. $2 \mathrm{~F}$ ), with a significant decrease in $\alpha$-Syn levels in the $20 \mathrm{nM}$ Gln group compared with the $10 \mathrm{nM}$ group $(\mathrm{P}<0.05)$. These results suggest that Gln treatment promotes $\alpha$-Syn degradation in PC12 $(\alpha-S y n+)$ cells.

Upregulation of Hsp70 by Gln inhibits proteasomal inhibitor-induced $\alpha$-Syn accumulation in PC12 ( $\alpha$-Syn+) cells. Proteasomal impairment has been suggested as another mechanism associated with abnormal $\alpha$-Syn accumulation in PD $(31,32)$. To investigate the regulation of proteasomal activity on $\alpha$-Syn degradation, the proteasomal activity and $\alpha$-Syn protein levels in PC12 $(\alpha-$ Syn +$)$ cells and normal PC12 cells, which were treated with Lac, were investigated. It was determined that treatment with 5 or $10 \mu \mathrm{M}$ Lac significantly reduced proteasomal activity in normal $\mathrm{PC} 12$ cells $(\mathrm{P}<0.01$ and $\mathrm{P}<0.001$, respectively; Fig. 3A), and in PC12 $(\alpha-S y n+)$ cells $(\mathrm{P}<0.001$ and $\mathrm{P}<0.0001$, respectively; Fig. 3B). This reduction was greater in cells treated with $10 \mu \mathrm{M}$ Lac than in those treated with $5 \mu \mathrm{M}$ Lac in both groups $[\mathrm{P}<0.05$ in $\mathrm{PC} 12$ cells; $\mathrm{P}<0.01$ in $\mathrm{PC} 12(\alpha-\mathrm{Syn}+)$ cells]. In addition, proteasomal activity in both types of PC12 cells was investigated following treatment with Gln. It was demonstrated that treatment with 5, 10 or $20 \mathrm{mM}$ Gln did not result in significant upregulation or downregulation of the proteasomal activity in PC12 (con) cells or in PC12 ( $\alpha$-Syn+) cells (Fig. 3C and D).

$\alpha$-Syn degradation in PC12 $(\alpha-S y n+)$ cells, which were treated with Gln and/or Lac, was subsequently evaluated. It was indicated that $\alpha$-Syn mRNA was not significantly altered following treatment with $10 \mathrm{mM} \mathrm{Gln}, 5 \mu \mathrm{M}$ Lac or both agents (10 mM Gln and $5 \mu \mathrm{M}$ Lac; Fig. 4A). However, western blotting demonstrated that proteasomal activity inhibition by 2,5 and $10 \mu \mathrm{M}$ Lac significantly upregulated $\alpha$-Syn accumulation in the PC12 $(\alpha-$ Syn + ) cells $(\mathrm{P}<0.05$ for $2 \mu \mathrm{M} ; \mathrm{P}<0.01$ for 5 and $10 \mu \mathrm{M})$, in a dose-dependent manner $(\mathrm{P}<0.05$ between 2 and $5 \mu \mathrm{M}$; Fig. 4B and C). However, Lac treatment for $24 \mathrm{~h}$ did not significantly regulate Hsp70 expression in PC12 ( $\alpha$-Syn+) cells (Fig. 4C). Furthermore, it was demonstrated that there is a reduction in Lac-induced $\alpha$-Syn accumulation following Gln treatment. As presented in Fig. 4D and E, $5 \mathrm{mM}$ Gln significantly reduced $2 \mu \mathrm{M}$ Lac-induced $\alpha$-Syn accumulation $(\mathrm{P}<0.05)$ and $10 \mathrm{mM}$ Gln significantly reduced the $5 \mu \mathrm{M}$ Lac-induced $\alpha$-Syn accumulation $(\mathrm{P}<0.01$; Fig. 4E). These findings suggest that the upregulation of Hsp70 by Gln may inhibit the proteasomal inhibitor-induced $\alpha$-Syn accumulation in PC12 ( $\alpha-$ Syn +$)$ cells.

\section{Discussion}

It has been recognized that hypofunction of molecular chaperones is associated with aberrant $\alpha$-Syn aggregation in 
$\mathbf{A}$

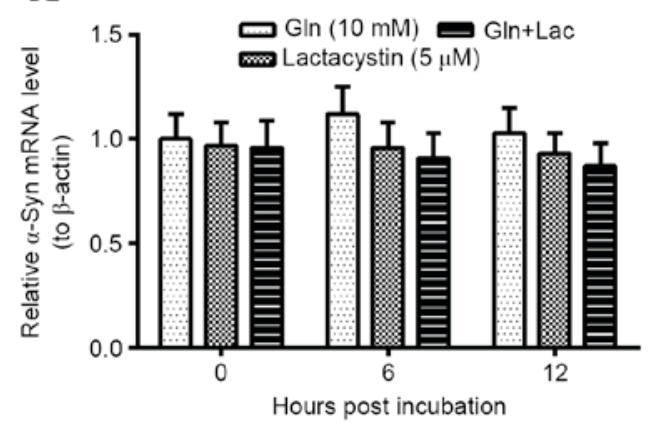

C

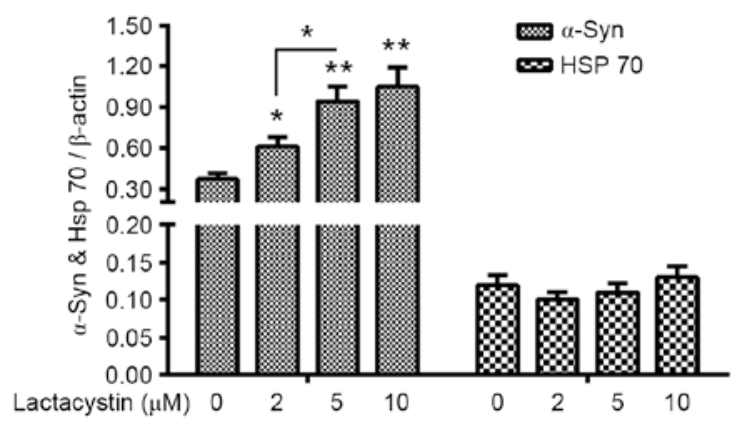

B

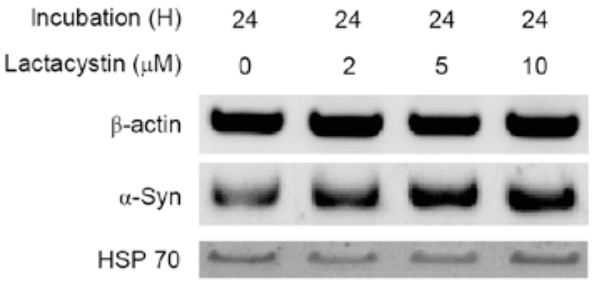

D

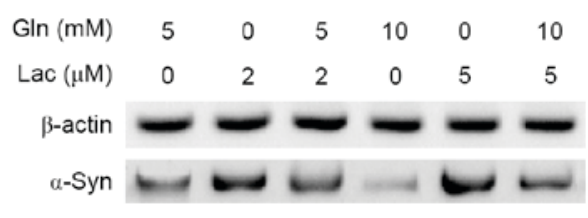

E

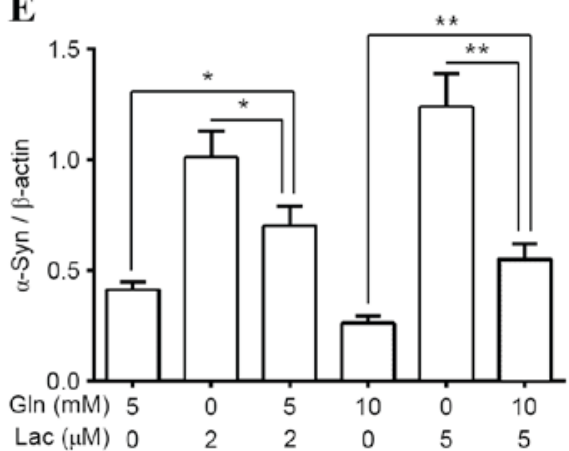

Figure 4. Gln reduces the proteasome inhibitor-promoted $\alpha$-Syn accumulation in neuroblastoma PC12 cells. (A) Levels of $\alpha$-Syn mRNA in PC12 ( $\alpha$-Syn+) cells treated with $10 \mathrm{mM}$ Gln and/or $5 \mu \mathrm{M}$ Lac for 6, 12 or $24 \mathrm{~h}$. (B and C) Western blot analysis of $\alpha$-Syn and Hsp70 in PC12 ( $\alpha$-Syn+) cells treated with 0 , 2, 5 or $10 \mu \mathrm{M}$ Lac for $24 \mathrm{~h}$. (D and E) Western blot analysis of $\alpha$-Syn in PC12 ( $\alpha$-Syn+) cells treated with 2 or $5 \mu \mathrm{M}$ Lac and/or 5 or $10 \mathrm{mM}$ Gln for $24 \mathrm{~h}$. All experiments were performed in triplicate and data are presented as the mean \pm standard deviation. ${ }^{*} \mathrm{P}<0.05,{ }^{* * *} \mathrm{P}<0.01 \mathrm{vs} .0 \mu \mathrm{M}$ Lac. Gln, glutamine; $\alpha$-Syn, $\alpha$-Synuclein; PC12 ( $\alpha$-Syn+), $\alpha$-Syn-overexpressed PC12; Lac, lactacystin; Hsp, heat shock protein.

PD $(19,20)$ and that Hsp promotion is effective at promoting $\alpha$-Syn degradation; Hsp70, in particular, has been confirmed to prevent $\alpha$-Syn aggregation in PD $(20,21)$. Previous studies have demonstrated that Hsp70 is subjected to transcriptional regulation upon different stresses and is regulated by a variety of molecules (32-34). It has previously been demonstrated that Gln enhances Hsp70 expression $(26,27,35)$. Gln mediates cellular protection against heat-stress injury to the lungs by promoting HSF-1 expression (26) or enhancing HSF-1 phosphorylation/activation (36). In the present study, Gln-regulated upregulation ofHsp70 expression was observed in PC12 cells at both the mRNA and protein levels in a dose- and time-dependent manner. The Gln-regulation of Hsp70 expression was demonstrated to be HSF-1-dependent via HSF-1 knockdown. HSF-1-specific siRNA was able to block HIF-1 expression and blunt Gln-promoted Hsp70 upregulation. These findings suggest that the Gln-promoted Hsp70 upregulation is HSF-1-dependent.

It has been suggested that in both sporadic and familial $\mathrm{PD}$, proteasomal impairment is associated with the abnormal accumulation of $\alpha$-Syn in PD pathogenesis $(30,31)$. The $\alpha$-Syn accumulation and the proteasomal inactivation may be associated with either the oxidative or the nonoxidative mode of dopamine toxicity (37) and accumulated $\alpha$-Syn subsequently induces toxicity in different cell lines or on isolated brain mitochondria $(38,39)$. The present study demonstrated that Gln treatment facilitated $\alpha$-Syn degradation but did not significantly regulate $\alpha$-Syn mRNA expression in PC12 $(\alpha-S y n+)$ cells, which overexpressed $\alpha$-Syn. This suggests that Gln may be a promising agent to ameliorate $\alpha$-Syn accumulation in PC12 $(\alpha$-Syn +$)$ cells. In addition, it was determined that although the regulatory role of Gln on $\alpha$-Syn accumulation was independent of proteasomal activity, it was able to reverse the inhibition of $\alpha$-Syn degradation, which was mediated by the proteasomal inhibitor Lac.

In conclusion, the present study demonstrated that Gln is able to promote Hsp70 in pheochromocytoma PC12 cells in an HSF-1-dependent manner and that Gln-promoted Hsp70 facilitates $\alpha$-Syn degradation proteasome-independently. These findings suggest that Gln may be a promising reagent to prevent $\alpha$-Syn aggregation in PD.

\section{Acknowledgements}

This study was supported by grants from the Natural Science Foundation of Heilongjiang Province (grant no. H201434), the Scientific Foundation of the First Affiliated Hospital of Harbin Medical University (grant no. 2011BS13), the Heilongjiang Postdoctoral Financial Assistance (grant no. LBH-Z11096), the International S\&T Cooperation Program of China (grant no. 
2014DFA31630) and the National Nature Science Foundation of China (grant no. 81571646).

\section{References}

1. Bertram L and Tanzi RE: The genetic epidemiology of neurodegenerative disease. J Clin Invest 115: 1449-1457, 2005.

2. Wirdefeldt K, Adami HO, Cole P, Trichopoulos D and Mandel J: Epidemiology and etiology of Parkinson's disease: A review of the evidence. Eur J Epidemiol 26 (Suppl 1): S1-S58, 2011.

3. Irizarry MC, Growdon W, Gomez-Isla T, Newell K, George JM, Clayton DF and Hyman BT: Nigral and cortical Lewy bodies and dystrophic nigral neurites in Parkinson's disease and cortical Lewy body disease contain alpha-synuclein immunoreactivity. J Neuropathol Exp Neurol 57: 334-337, 1998.

4. Spillantini MG, Crowther RA, Jakes R, Hasegawa M and Goedert M: Alpha-Synuclein in filamentous inclusions of Lewy bodies from Parkinson's disease and dementia with lewy bodies. Proc Natl Acad Sci USA 95: 6469-6473, 1998.

5. Jellinger KA: Neuropathology of sporadic Parkinson's disease: Evaluation and changes of concepts. Mov Disord 27: 8-30, 2012.

6. Ueda K, Fukushima H, Masliah E, Xia Y, Iwai A, Yoshimoto M, Otero DA, Kondo J, Ihara Y and Saitoh T: Molecular cloning of cDNA encoding an unrecognized component of amyloid in Alzheimer disease. Proc Natl Acad Sci USA 90: 11282-11286, 1993.

7. Jakes R, Spillantini MG and Goedert M: Identification of two distinct synucleins from human brain. Febs Lett 345: 27-32, 1994.

8. Bartels T, Choi JG and Selkoe DJ: $\alpha$-Synuclein occurs physiologically as a helically folded tetramer that resists aggregation. Nature 477: 107-110, 2011.

9. Mueller A, Ziegler K, Amsharov KY and Jansen M: Perchloropyracylene and its fusion with $\mathrm{C} 60$ by chlorine-assisted radio-frequency furnace synthesis. Chemistry 17: 11797-11804, 2011.

10. Eichner T and Radford SE: A diversity of assembly mechanisms of a generic amyloid fold. Mol Cell 43: 8-18, 2011.

11. Kruger R, Kuhn W, Müller T, Woitalla D, Graeber M, Kösel S, Przuntek H, Epplen JT, Schöls L and Riess O: Ala30Pro mutation in the gene encoding alpha-synuclein in Parkinson's disease. Nat Genet 18: 106-108, 1998.

12. Chartier-Harlin MC, Kachergus J, Roumier C, Mouroux V, Douay X, Lincoln S, Levecque C, Larvor L, Andrieux J, Hulihan M, et al: Alpha-synuclein locus duplication as a cause of familial Parkinson's disease. Lancet 364: 1167-1169, 2004.

13. Singleton AB, Farrer M, Johnson J, Singleton A, Hague S, Kachergus J, Hulihan M, Peuralinna T, Dutra A, Nussbaum R, et al: Alpha-Synuclein locus triplication causes Parkinson's disease. Science 302: 841, 2003.

14. Alvarez-Erviti L, Seow Y, Schapira AH, Rodriguez-Oroz MC, Obeso JA and Cooper JM: Influence of microRNA deregulation on chaperone-mediated autophagy and $\alpha$-synuclein pathology in Parkinson's disease. Cell Death Dis 4: e545, 2013.

15. Cuervo AM, Stefanis L, Fredenburg R, Lansbury PT and Sulzer D: Impaired degradation of mutant alpha-synuclein by chaperone-mediated autophagy. Science 305: 1292-1295, 2004.

16. Alvarez-Erviti L, Rodriguez-Oroz MC, Cooper JM, Caballero C, Ferrer I, Obeso JA and Schapira AH: Chaperone-mediated autophagy markers in Parkinson disease brains. Arch Neurol 67: 1464-1472, 2010.

17. Wacker JL, Zareie MH, Fong H, Sarikaya M and Muchowski PJ: Hsp70 and Hsp40 attenuate formation of spherical and annular polyglutamine oligomers by partitioning monomer. Nat Struct Mol Biol 11: 1215-1222, 2004.

18. Periquet M, Fulga T, Myllykangas L, Schlossmacher MG and Feany MB: Aggregated alpha-synuclein mediates dopaminergic neurotoxicity in vivo. J Neurosci 27: 3338-3346, 2007.

19. Auluck PK, Chan HY, Trojanowski JQ, Lee VM and Bonini NM: Chaperone suppression of alpha-synuclein toxicity in a Drosophila model for Parkinson's disease. Science 295: 865-868, 2002.
20. Klucken J, Shin Y, Masliah E, Hyman BT and McLean PJ: Hsp70 reduces alpha-synuclein aggregation and toxicity. J Biol Chem 279: 25497-25502, 2004.

21. Luk KC, Mills IP, Trojanowski JQ and Lee VM: Interactions between Hsp70 and the hydrophobic core of alpha-synuclein inhibit fibril assembly. Biochemistry 47: 12614-12625, 2008.

22. Wang R, Zhao J, Zhang J, Liu W, Zhao M, Li J, Lv J and Li Y: Effect of lysosomal and ubiquitin-proteasome system dysfunction on the abnormal aggregation of $\alpha$-synuclein in PC12 cells Exp Ther Med 9: 2088-2094, 2015.

23. Weissman AM: Themes and variations on ubiquitylation. Nat Rev Mol Cell Biol 2: 169-178, 2001.

24. Davies SE, Hallett PJ, Moens T, Smith G, Mangano E, Kim HT, Goldberg AL, Liu JL, Isacson O and Tofaris GK: Enhanced ubiquitin-dependent degradation by Nedd4 protects against $\alpha$-synuclein accumulation and toxicity in animal models of Parkinson's disease. Neurobiol Dis 64: 79-87, 2014.

25. Livak KJ and Schmittgen TD: Analysis of relative gene expression data using real-time quantitative PCR and the 2(-Delta Delta C(T)) method. Methods 25: 402-408, 2001.

26. Morrison AL, Dinges M, Singleton KD, Odoms K, Wong HR and Wischmeyer PE: Glutamine's protection against cellular injury is dependent on heat shock factor-1. Am J Physiol Cell Physiol 290: C1625-C1632, 2006.

27. Singleton KD and Wischmeyer PE: Glutamine's protection against sepsis and lung injury is dependent on heat shock protein 70 expression. Am J Physiol Regul Integr Comp Physiol 292: R1839-R1845, 2007.

28. Yang J, Zhang Y, Zhao S, Zhang Z, Tong X, Wei F and Lu Z: Heat shock protein 70 induction by glutamine increases the alphasynuclein degradation in SHSY5Y neuroblastoma cells. Mol Med Rep 12: 5524-5530, 2015.

29. Zhang J, Liu B, Li J, Zhang L, Wang Y, Zheng H, Lu M and Chen J: Hsf and Hsp gene families in Populus: Genome-wide identification, organization and correlated expression during development and in stress responses. BMC Genomics 16: 181, 2015.

30. McNaught KS, Belizaire R, Jenner P, Olanow CW and Isacson O: Selective loss of $20 \mathrm{~S}$ proteasome alpha-subunits in the substantia nigra pars compacta in Parkinson's disease. Neurosci Lett 326: $155-158,2002$.

31. McNaught KS, Belizaire R, Isacson O, Jenner P and Olanow CW: Altered proteasomal function in sporadic Parkinson's disease. Exp Neurol 179: 38-46, 2003

32. Song Y and Masison DC: Independent regulation of Hsp70 and Hsp90 chaperones by Hsp70/Hsp90-organizing protein Sti1 (Hop1). J Biol Chem 280: 34178-34185, 2005.

33. Fukayama S, Lanske B, Guo J, Kronenberg HM and Bringhurst FR: Regulation of HSP70 by PTH: A model of gene regulation not mediated by changes in cAMP levels. Am J Physiol 271: C121-C129, 1996.

34. Jacquier-Sarlin MR, Jornot L and Polla BS: Differential expression and regulation of hsp70 and hsp90 by phorbol esters and heat shock. J Biol Chem 270: 14094-14099, 1995.

35. Wischmeyer PE, Kahana M, Wolfson R, Ren H, Musch MM and Chang EB: Glutamine induces heat shock protein and protects against endotoxin shock in the rat. J Appl Physiol (1985) 90: 2403-2410, 2001

36. Singleton KD, Serkova N, Beckey VE and Wischmeyer PE: Glutamine attenuates lung injury and improves survival after sepsis: Role of enhanced heat shock protein expression. Crit Care Med 33: 1206-1213, 2005.

37. Banerjee K, Munshi S, Sen O, Pramanik V, Roy MT and Chakrabarti S: Dopamine cytotoxicity involves both oxidative and nonoxidative pathways in SH-SY5Y cells: Potential role of alpha-synuclein overexpression and proteasomal inhibition in the etiopathogenesis of Parkinson's disease. Parkinsons Dis 2014: 878935, 2014

38. Zhou W, Hurlbert MS, Schaack J, Prasad KN and Freed CR: Overexpression of human alpha-synuclein causes dopamine neuron death in rat primary culture and immortalized mesencephalon-derived cells. Brain Res 866: 33-43, 2000.

39. Bisaglia M, Greggio E, Maric D, Miller DW, Cookson MR and Bubacco L: Alpha-synuclein overexpression increases dopamine toxicity in BE2-M17 cells. BMC Neurosci 11: 41, 2010. 